\title{
Methanobacterium thermoautotrophicus Should Be Methanobacterium thermoautotrophicum
}

J. G. ZEIKUS and R. S. WOLFE

Department of Microbiology, University of Illinois, Urbana, Illinois 61801

After the paper entitled "Methanobacterium thermoautotrophicus sp. n., an Anaerobic, Autotrophic, Extreme Thermophile" was published (J. Bacteriol. 109:707-713, 1972), it was called to our attention by E. F. Lessel and R. E. Buchanan that the spelling of the specific epithet should be thermoautotrophicum, not thermoautotrophicus, to agree with the neuter gender of the generic name Methanobacterium.

It is here proposed that the spelling of the specific epithet be so changed, and the correct name of the organism is therefore Methanobacterium thermoautotrophicum. 